\title{
Accuracy of Non-Contrast MRI for the Detection of Hepatocellular Carcinoma: A systematic review and meta-analysis
}

\author{
Liping Lu ${ }^{1}$, Xuming Pan ${ }^{2}$
}

\begin{abstract}
Non-contrast MRI is used for identifying patients with hepatocellular carcinoma (HCC), especially among high-risk patients with cirrhosis or chronic viral hepatitis. The accuracy of non-contrast MRI has been investigated with varying results. We performed this meta-analysis to consolidate the evidence on the accuracy of non-contrast MRI for the detection of HCC. We conducted a systematic search in the databases of PubMed Central, SCOPUS, MEDLINE, EMBASE and Cochrane from inception till November 2020. We used the STATA software "Midas" package for meta-analysis. We included 15 studies with 3,756 patients. The pooled sensitivity and specificity of non-contrast MRI for HCC detection were $84 \%(95 \% \mathrm{Cl}, 78 \%-88 \%)$ and $94 \%(95 \% \mathrm{Cl}, 91 \%-97 \%)$. The positive likelihood ratio was $14.9(95 \% \mathrm{Cl}, 9.0-24.7)$ and the negative one 0.17 $(0.12-0.23)$. The overall quality of the studies was high. We found significant heterogeneity based on chisquare test results and $\mathrm{I}^{2}$ statistic $>75 \%$. Deek's test showed the absence of publication bias. We found that non-contrast MRI has high sensitivity and specificity as a tool for detecting HCC. Studies exploring its accuracy in different ethnic populations are required to strengthen the evidence.
\end{abstract}

KEYWORDS: Hepatocellular Carcinoma, Magnetic Resonance Imaging, Meta-analysis, Validation studies.

How to cite this:

doi: https://doi.org/10.12669/pjms.38.3.5142

Lu L, Pan X. Accuracy of Non-Contrast MRI for the Detection of Hepatocellular Carcinoma: A systematic review and meta-analysis. Pak J Med Sci. 2022;38(3):743-750. doi: https://doi.org/10.12669/pjms.38.3.5142

This is an Open Access article distributed under the terms of the Creative Commons Attribution License (http://creativecommons.org/licenses/by/3.0), which permits unrestricted use, distribution, and reproduction in any medium, provided the original work is properly cited.

\section{INTRODUCTION}

Most patients with hepatocellular carcinoma (HCC) are diagnosed when presenting advanced cancer stages, making it difficult for curative treatments to work. ${ }^{1}$ Prevention or treatment of hepatitis infection, regular surveillance to

1. Liping Lu,

Huzhou Third Municipal Hospital,

the Affiliated Hospital of Huzhou University,

Huzhou, Zhejiang Province, China.

2. Xuming Pan,

Huzhou Traditional Chinese Medicine Hospital

Affiliated to Zhejiang Chinese Medical University,

Huzhou, Zhejiang Province, China.

Correspondence:

Xuming Pan,

Huzhou Traditional Chinese Medicine Hospital

Affiliated to Zhejiang Chinese Medical University,

No. 315 South Street, Wuxing Area,

Huzhou 313000, Zhejiang Province, China.

E-mail: pxm_dr@163.com

* Received for Publication:

July 12, 2021

* Revision Received:

August 9, 2021 diagnose HCC early, and prompt management are the most effective ways to reduce the mortality of HCC. ${ }^{2}$ Surveillance strategies target patients with high risk of presenting HCC such as those with liver cirrhosis or viral hepatitis, and they help to increase the number of HCC patients diagnosed with a potentially curable disease, thereby improving the HCC-related mortality. ${ }^{3}$

The European Association for Study of Liver (EASL), American Association for the Study of the Liver Diseases (AASLD), and Asian Pacific Association for Study of Liver have recommended a surveillance strategy for patients with HCC risk factors with biannual ultrasonography (USG) ${ }^{4-7}$ However, the accuracy of USG for detecting HCC is unsatisfactory. USG is only $63 \%$ sensitive for diagnosing early HCC, leading to delayed diagnoses in more than one-third of patients. ${ }^{8}$ Hence, alternate diagnostic tools for HCC need to be explored.

Possible alternatives for HCC diagnostics include contrast enhanced magnetic resonance imaging 
(MRI) and non-contrast MRI with or without diffuse weighted imaging (DWI) as a screening tool. ${ }^{9}$ However, use of intravenous (IV) contrast agents such as gadolinium for enhanced MRI are not widely acceptable for undertaking largescale screening programmes due to controversies related to deposition of gadolinium in the body tissues and to its high costs. ${ }^{10}$ Hence, non-contrast MRI may be a more accepted alternative to USG for the detection of HCC. But, no systematic effort to pool all the evidence and provide a final answer on its accuracy to detect HCC has made. Our aim with this study was to conduct a detailed literature search and to synthesize the outcome data from studies reporting the accuracy of non-contrast MRI for the detection of HCC.

\section{METHODS}

Eligibility Criteria: We have included the studies assessing the accuracy of non-contrast MRI amongst the patients suspected to have HCC irrespective of study design. The reference standards for HCC detection included histopathology, biopsy, and contrast-enhanced MRI. We excluded unpublished studies and grey literature.

Search Strategy: We conducted an explicit, comprehensive, and systematic search on PubMed Central (PMC), SCOPUS, MEDLINE, EMBASE and Cochrane databases. We used the PubMed search engine to search the PMC and MEDLINE databases. We used the following set of medical subject headings (MeSH) and free-text terms to search the databases from inception until November 2020: "Magnetic Resonance Imaging", "Non-contrast MRI", "Validation Studies", "Hepatocellular Carcinoma", "Tumours of the Liver", "Diagnostic Accuracy Studies", "Liver Tumours", and "Liver Malignancy". We did not set language restrictions, and we manually reviewed the references of the identified articles.

Two authors independently performed the initial screening by checking the title, abstract, and keywords of papers in the search results, and they downloaded the relevant full-text publications. Then, the same two authors independently read the downloaded full-texts to include the studies meeting our eligibility criteria in the review.

Data Extraction: Primary investigator extracted the data using a pre-defined data extraction form. The data extraction included: publication year, author information, country/residence, region, setting, participants, design, total sample size, details of non-contrast MRI procedure and technique, reference standard, average age, sensitivity, and specificity. Another investigator ensured the quality of the data entry procedure by double checking the entries before performing the analysis.

Quality assessment of diagnostic accuracy studies-2: (QUADAS-2) tool was used to assess the risk of bias under the domains: patient selection, conducting and interpreting the index and reference standard tests, and outcome assessment flow and timing ${ }^{11}$ and graded all the studies as having low, high, or unclear risk of bias.

Statistical Analysis: We pool the sensitivity and specificity indices of non-contrast MRI for the detection of HCC based on a bivariate metaanalysis. We calculated positive and negative likelihood ratios (LRP and LRN) and diagnostic odds ratio (DOR) for the utility of non-contrast MRI. Our results are reported on forest plots (pooled specificity and sensitivity), LR scattergrams (LRP and LRN) and Fagan's plots (pre- and post-test probability of detecting HCC). We calculated the chi-square and $\mathrm{I}^{2}$ statistic to assess heterogeneity between the studies.

Additional subgroup analysis was performed based on the intent of imaging (diagnostic/ surveillance), condition of study participants and use of DWI. We performed meta-regression to find out the source of heterogeneity. The covariates adjusted during the meta-regression were study design, country, sample size, intent of source imaging, mean age, and quality related factors. We used Deek's test to assess publication bias. Sensitivity analysis was performed to assess the robustness of the study results. We performed all analyses using the STATA software Midas command package.

\section{RESULTS}

We found 978 records through the systematic literature search, and deemed 109 of those studies relevant for full-text retrieval. We also retrieved full-texts for nine articles obtained through manual searching of the bibliographies. During the second screening stage, 15 studies with 3,756 participants met the eligibility criteria (Fig.1). ${ }^{12-26}$

Most studies (12 out of 15 studies) were retrospective. Almost half of the studies were conducted in Korea (7 out 15 studies). The average age of the patients ranged from 56 to 66.2 years. The MRI indications were almost equally distributed between diagnosis and surveillance, and most studies used histopathology/biopsy following surgery as the reference standard (Table-I). 
Table-I: Characteristics of the included studies $(n=15)$

\begin{tabular}{|c|c|c|c|c|c|}
\hline $\begin{array}{l}\text { Author, year, } \\
\text { Country }\end{array}$ & $\begin{array}{l}\text { Study } \\
\text { design }\end{array}$ & Study participants & MRI Procedure and Intent & $\begin{array}{l}\text { Reference } \\
\text { standard }\end{array}$ & $\begin{array}{l}\text { Mean } \\
\text { age (in } \\
\text { years) }\end{array}$ \\
\hline $\begin{array}{l}\text { Chan et al } \\
2019^{19} \text { Aus- } \\
\text { tralia }\end{array}$ & $\begin{array}{l}\text { Retro- } \\
\text { spective }\end{array}$ & $\begin{array}{l}564 \text { patients at high risk } \\
\text { of } \mathrm{HCC} \text { (cirrhosis, HBV/ } \\
\text { hepatitis } \mathrm{C} \text { virus / other } \\
\text { risk factors) for HCC } \\
\text { diagnosis }\end{array}$ & $\begin{array}{l}\text { Non-contrast MRI study created by } \\
\text { selecting axial T2- weighted sequence } \\
\text { with } 160 \text {-ms echo time, all four axial T1- } \\
\text { weighted Dixon sequences }\end{array}$ & cMRI & 63 \\
\hline $\begin{array}{l}\text { Chung et al } \\
2011^{21} \text { Korea }\end{array}$ & $\begin{array}{l}\text { Retro- } \\
\text { spective }\end{array}$ & $\begin{array}{l}46 \text { patients who under- } \\
\text { went hepatic MRI for } \\
\text { HCC surveillance }\end{array}$ & $\begin{array}{l}\text { DWI on a single-shot spin-echo Echo } \\
\text { Planar Imaging sequence that combined } \\
\text { the two diffusion gradients before \& after } \\
180^{\circ} \text { pulse }\end{array}$ & $\begin{array}{l}\text { Histopa- } \\
\text { thology }\end{array}$ & 59.6 \\
\hline $\begin{array}{l}\text { Han et al } \\
2018^{25} \text { Korea }\end{array}$ & $\begin{array}{l}\text { Retro- } \\
\text { spective }\end{array}$ & $\begin{array}{l}247 \text { patients with initial } \\
\text { diagnosed HCC \& no } \\
\text { previous treatment his- } \\
\text { tory, within Milan criteria } \\
\text { for HCC diagnosis }\end{array}$ & $\begin{array}{l}\text { Liver MRIs on a 3T system with an } \\
\text { 8-channel phased array torso coil. Res- } \\
\text { piratory triggered fast spin echo T2WI } \\
\text { with fat suppression \& dual gradient } \\
\text { echo T1WI using in-phase and opposed- } \\
\text { phase }\end{array}$ & $\begin{array}{l}\text { Histopa- } \\
\text { thology/ } \\
\text { cMRI/FU }\end{array}$ & 59.6 \\
\hline $\begin{array}{l}\text { Hardie et al } \\
2011^{15} \text { USA }\end{array}$ & $\begin{array}{l}\text { Retro- } \\
\text { spective }\end{array}$ & $\begin{array}{l}37 \text { patients who had un- } \\
\text { dergone liver transplan- } \\
\text { tation for HCC diagnosis }\end{array}$ & $\begin{array}{l}\text { DWI on a single-shot echo-planar imag- } \\
\text { ing with repetition time/echo time } \\
4800 / 94 \text {; matrix } 192 ¥ 100 \text {; parallel imag- } \\
\text { ing factor } 2 \text {; gradients with b-value 50, } \\
500,1000 \mathrm{~s} / \mathrm{mm}^{2}\end{array}$ & $\begin{array}{l}\text { Histopa- } \\
\text { thology }\end{array}$ & 56.6 \\
\hline $\begin{array}{l}\text { Jalli et al } \\
2015^{13} \text { Iran }\end{array}$ & $\begin{array}{l}\text { Prospec- } \\
\text { tive }\end{array}$ & $\begin{array}{l}96 \text { cirrhosis patients } \\
\text { referred to gastroenterol- } \\
\text { ogy follow-up for HCC } \\
\text { diagnosis }\end{array}$ & $\begin{array}{l}\text { Respiratory triggered single-shot fat- } \\
\text { suppressed echo-planar DWI sequence in } \\
\text { axial plane with acquisition correction on } \\
\text { TR/TE, } 2100 / 85 \mathrm{~ms} ; 6 \mathrm{~mm} \text { slice thickness; } \\
\text { with b value } 50,400,800 \mathrm{~s} / \mathrm{mm}^{2}\end{array}$ & $\begin{array}{l}\text { Histopa- } \\
\text { thology }\end{array}$ & NA \\
\hline $\begin{array}{l}\text { Kim et al } \\
2014^{22} \text { Korea }\end{array}$ & $\begin{array}{l}\text { Retro- } \\
\text { spective }\end{array}$ & $\begin{array}{l}182 \text { patients with chronic } \\
\text { hepatitis or liver cirrhosis } \\
\text { for HCC diagnosis }\end{array}$ & $\begin{array}{l}\text { DW-MRI single-shot echo planar imag- } \\
\text { ing and simultaneous respiratory trigger- } \\
\text { ing on TR/TE } 1600 / 70 \text {. b-value of } 0,100 \text {, } \\
800 \mathrm{~s} / \mathrm{mm}^{2} \text {; SENSE acceleration factor, } \\
4.0 \text {; field-of-view, } 35 \times 35 \mathrm{~cm} \text {; }\end{array}$ & $\begin{array}{l}\text { Histopa- } \\
\text { thology }\end{array}$ & 57 \\
\hline $\begin{array}{l}\text { Kim et al } \\
2020^{16} \text { Korea }\end{array}$ & $\begin{array}{l}\text { Retro- } \\
\text { spective }\end{array}$ & $\begin{array}{l}226 \text { patients with a histo- } \\
\text { ry of cirrhosis or chronic } \\
\text { liver disease who under- } \\
\text { went MRI of the liver for } \\
\text { HCC surveillance }\end{array}$ & $\begin{array}{l}\text { Liver MRI scans on a 3T system with a16- } \\
\text { channel phased-array torso coil. Respira- } \\
\text { tory-triggered fast-spin echo T2WI with } \\
\text { fat suppression and dual-gradient echo } \\
\text { T1WI. DWI with echo planar imaging us- } \\
\text { ing b values of } 0,50,400,800 \mathrm{~s} / \mathrm{mm}^{2}\end{array}$ & $\begin{array}{l}\text { Histopa- } \\
\text { thology }\end{array}$ & 60.1 \\
\hline $\begin{array}{l}\text { Min et al } \\
2018^{14} \text { Korea }\end{array}$ & $\begin{array}{l}\text { Retro- } \\
\text { spective }\end{array}$ & $\begin{array}{l}483 \text { patients who under- } \\
\text { went surveillance after } \\
\text { hepatectomy }\end{array}$ & $\begin{array}{l}\text { MR images on a } 3.0 \mathrm{~T} \text { whole-body MR } \\
\text { system with a 16-channel phased-array } \\
\text { coil as the receiver coil. }\end{array}$ & $\begin{array}{l}\text { Histopa- } \\
\text { thology }\end{array}$ & 58 \\
\hline $\begin{array}{l}\text { Park et al } \\
2012^{20} \text { USA }\end{array}$ & $\begin{array}{l}\text { Retro- } \\
\text { spective }\end{array}$ & $\begin{array}{l}52 \text { patients who under- } \\
\text { went liver transplantation } \\
\text { for HCC surveillance }\end{array}$ & $\begin{array}{l}\text { Liver MRI on different state-of-the-art } \\
1.5-\mathrm{T} \text { systems and torso phased-array } \\
\text { coils. Parallel imaging and field of view } \\
\text { of } 300-400 \mathrm{~mm}\end{array}$ & $\begin{array}{l}\text { Histopa- } \\
\text { thology }\end{array}$ & 56 \\
\hline $\begin{array}{l}\text { Park et al } \\
2020^{23} \text { Korea }\end{array}$ & $\begin{array}{l}\text { Retro- } \\
\text { spective }\end{array}$ & $\begin{array}{l}1057 \text { patients }>20 \text { years } \\
\text { diagnosed histologically/ } \\
\text { radiologically as hav- } \\
\text { ing cirrhosis with HCC } \\
\text { surveillance }\end{array}$ & $\begin{array}{l}\text { MRI on a 1.5-T scanner. Breath-hold dual } \\
\text { gradient-echo T1-weighted images, DWI } \\
\text { with a respiratory triggered turbo spin } \\
\text { echo, single-shot echo planar sequence } \\
\text { images with b-values of } 0,50,500 \mathrm{~s} / \mathrm{mm}^{2}\end{array}$ & $\begin{array}{l}\text { Histo- } \\
\text { pathol- } \\
\text { ogy and } \\
\text { radiologic } \\
\text { hallmark }\end{array}$ & 56.4 \\
\hline
\end{tabular}




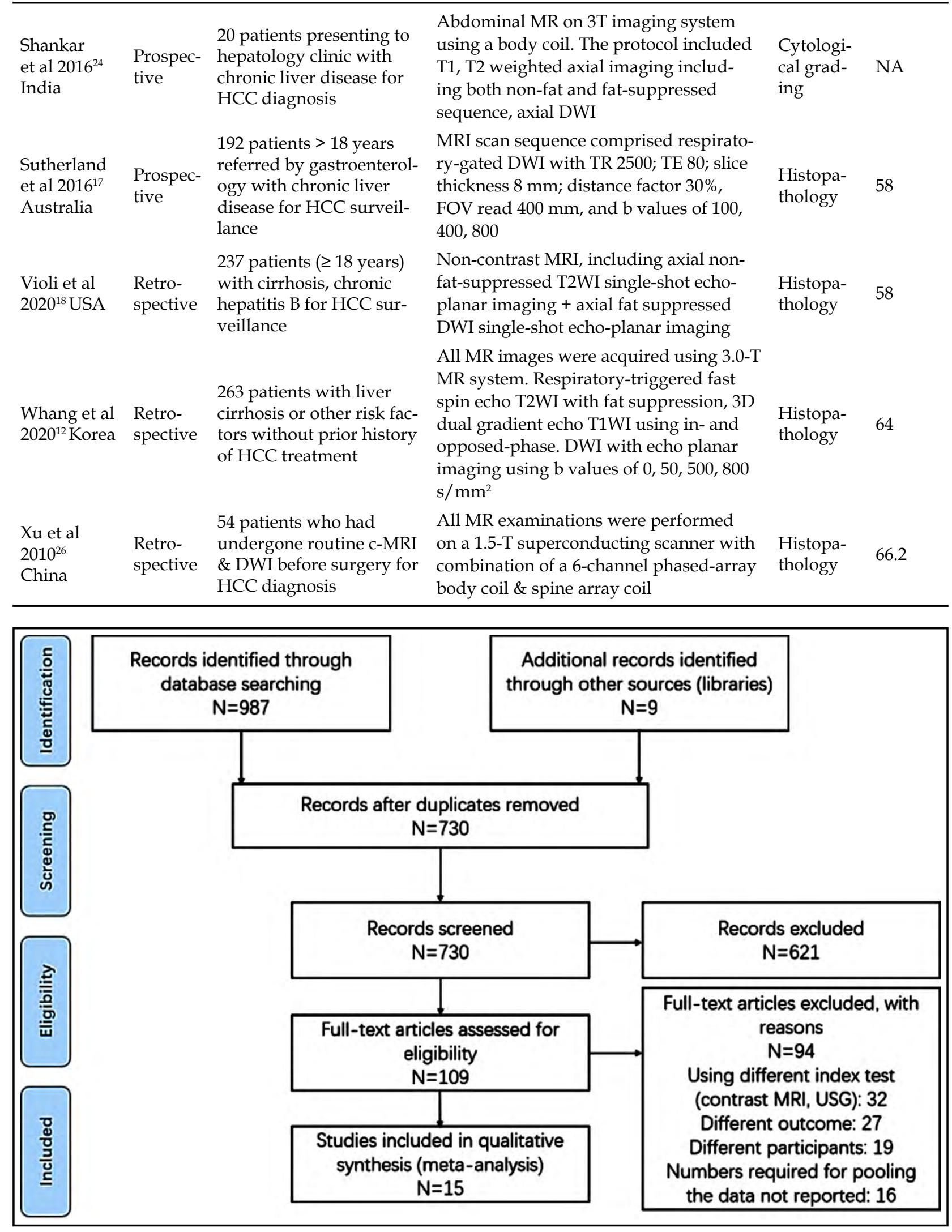

Fig.1: Search strategy. 


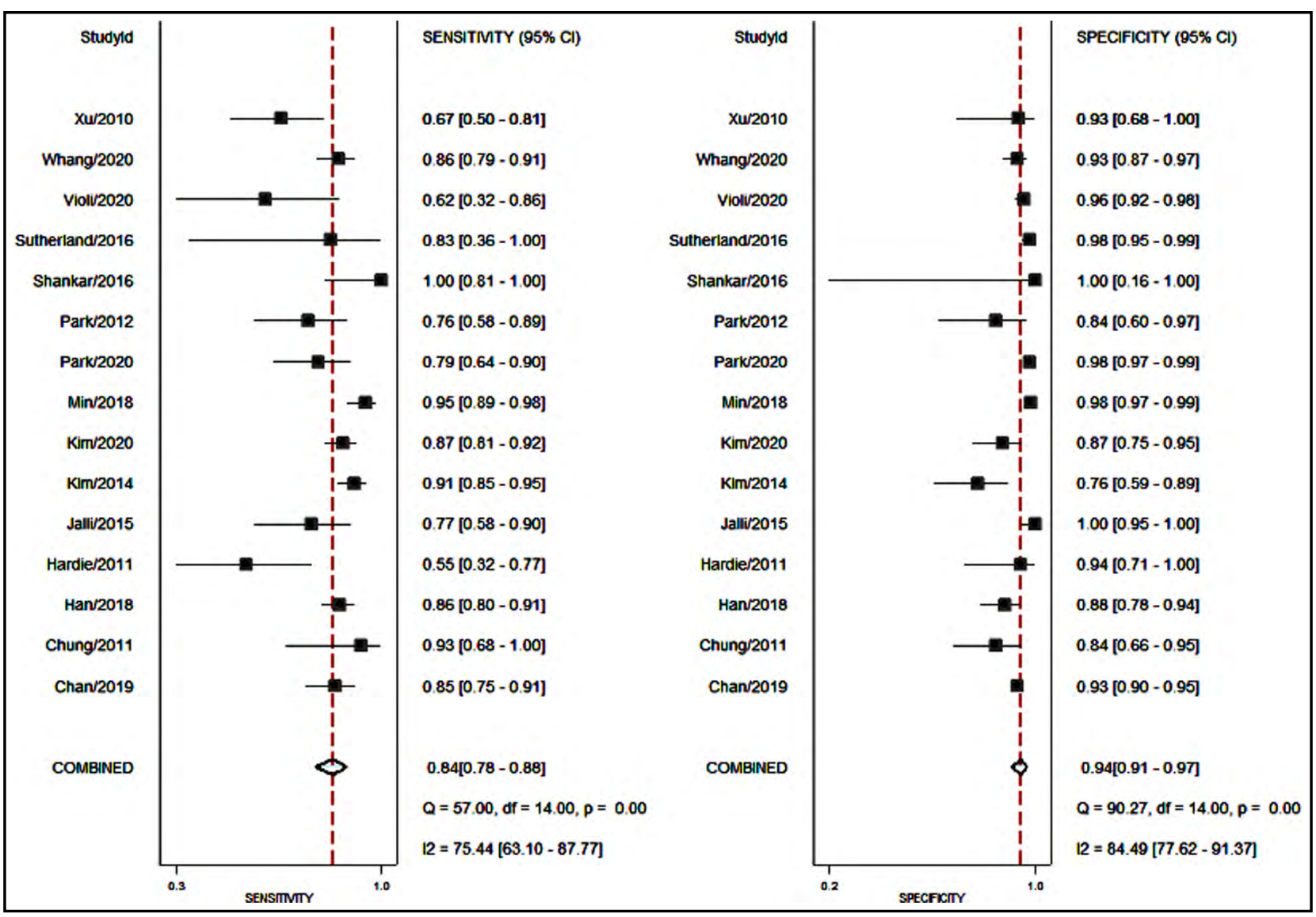

Fig.2: Forest plot showing pooled sensitivity and specificity for non-contrast MRI.

We found that nine out of 15 studies had a high patient selection bias risk, six had a high conduct and interpretation of index test bias risk, 5 had a high patient flow and interval between index tests and reference standards bias risk, and none had a high reference standard bias risk.

The utility of non-contrast MRI for the detection of HCC was reported in 15 studies. ${ }^{12-26}$ The pooled sensitivity and specificity of non-contrast MRI for HCC among high-risk patients were 84\% (95\% CI, $78 \%-88 \%$ ) and $94 \%$ (95\% CI, 91\%-97\%), respectively (Fig. 2). The DOR was 87 (95\% CI, 47-160). LRP was 14.9 (95\% CI, 9.0-24.7) and LRN was 0.17 (0.12-0.23). The LR scattergram (Fig.3) shows that the LRP and LRN are in the right upper quadrant indicating that non-contrast MRI can be used for confirmation only. Fagan's nomogram (Fig.4) shows a high clinical utility of non-contrast MRI for HCC detection (Positive $=85 \%$; Negative $=6 \%$ ) differing significantly from the pre-test probability $(28 \%)$. We also found significant heterogeneity with chi-square $\mathrm{p}$-value $<0.001$ and $\mathrm{I}^{2}=91 \%$.

Subgroup analysis based on intent of imaging showed that the non-contrast MRI is more accurate when it is used as surveillance tool (pooled sensitivity $=85 \%$ \& specificity $=95 \%$ ) than diagnostic tool (pooled sensitivity $=83 \%$ \& specificity $=93 \%$ ). Sensitivity and specificity among the cirrhosis/

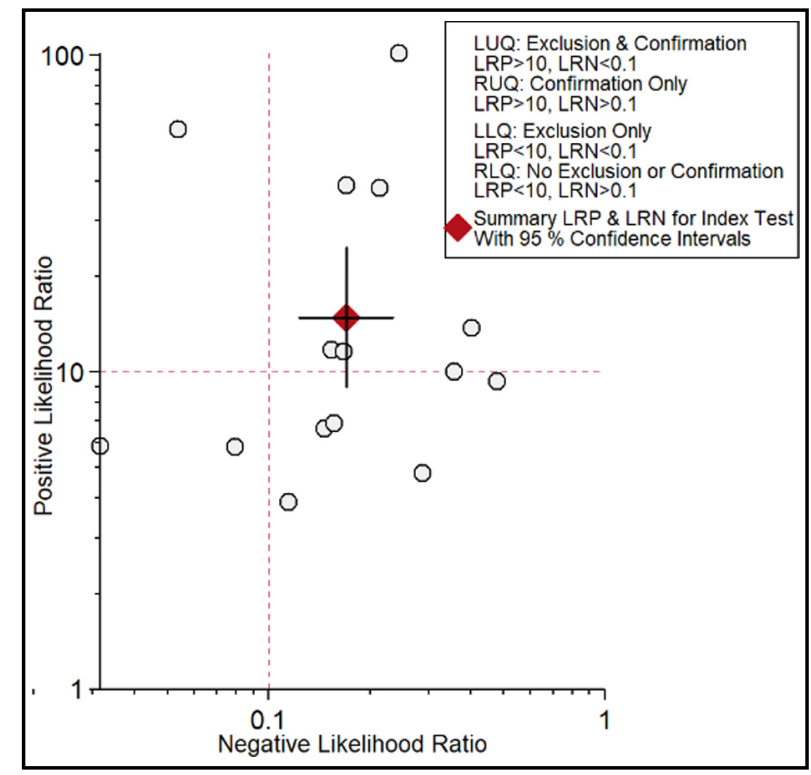

Fig.3: Likelihood scatter gram. 
Liping Lu et al.

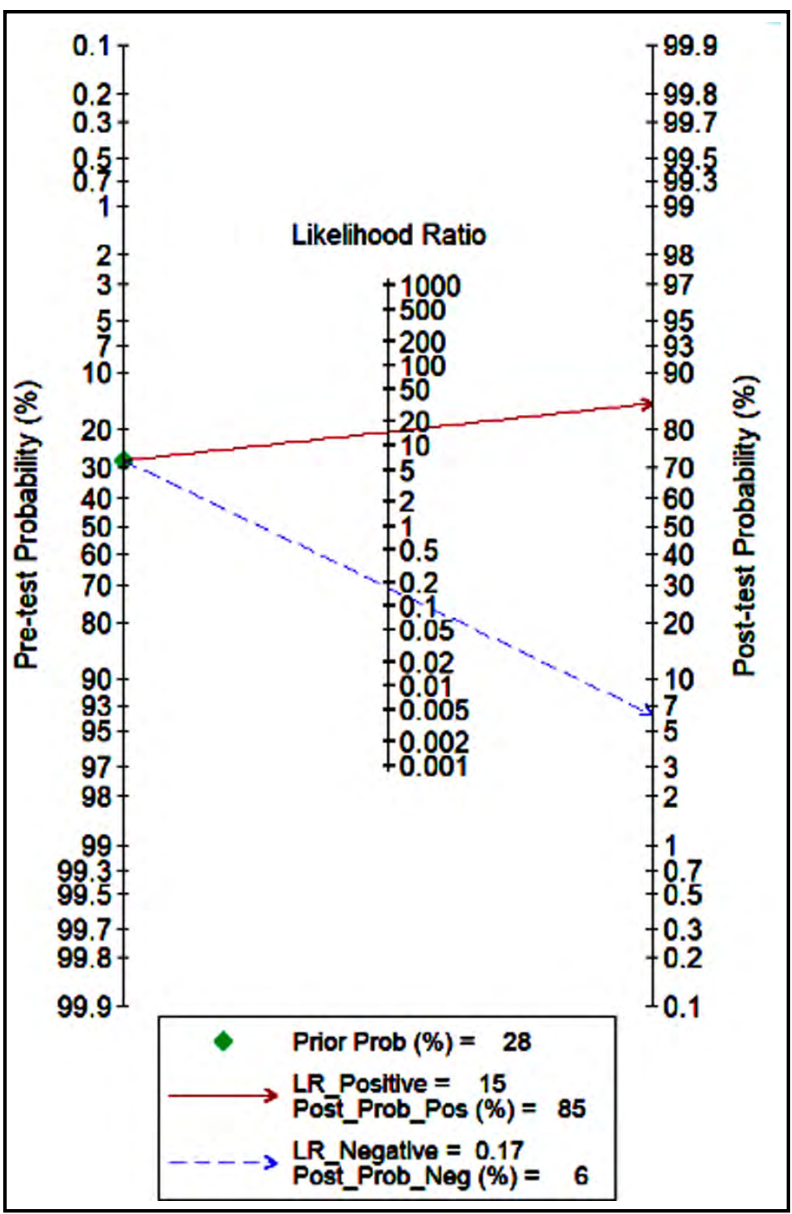

Fig.4: Fagan nomogram

chronic hepatitis/chronic liver condition patients were $84 \%$ and $95 \%$. Use of DWI imaging did not significantly differ the sensitivity $(82 \%)$ and specificity $(95 \%)$ compared to overall estimates.

Meta-regression results indicate that index test standards $(p<0.001)$ and flow and timing of tests $(p<0.001)$ was the sources of heterogeneity in sensitivity model, study design $(p=0.04)$ and patient selection $(p=0.03)$ were significant in specificity model, and mean age was the source of heterogeneity in the joint model $(\mathrm{p}<0.001)$. Deek's test showed a non-significant $p$-value $(p=0.21)$ indicating the absence of publication bias. Sensitivity analysis revealed there was no significant single study effects or effect from inflated pre-test probability on the accuracy of the non-contrast MRI for HCC.

\section{DISCUSSION}

The MR imaging system is used for identifying patients with HCC, especially among those with high-risk of developing the malignancy (patients with cirrhosis and chronic hepatitis infection). Non-contrast MRIs can be used as they are less time consuming, easier to obtain, carry lower healthcare costs, and prevent the harmful effects associated with the contrast agents on dynamic contrast enhanced MRIs. However, the evidence of their utility has not been synthesized. Hence, our goal with this review was to determine the accuracy of non-contrast MRI for the detection of HCC, especially amongst high-risk patients.

After the systematic literature search, we found 15 studies (most retrospective in nature and with low bias risks) reporting the utility of non-contrast MRI for HCC. We found a high pooled sensitivity $(84 \%)$ and specificity $(94 \%)$ for non-contrast MRI in HCC detection. Other accuracy parameters also showed a high accuracy: in the LR scattergram, LRN and LRP occupied the right upper quadrant indicating that the imaging technique can be used for both HCC confirmation. The clinical utility of non-contrast MRI was also significantly better as the Fagan's nomogram showed a significant rise in the post-MRI probability compared to the pre-MRI probability.

The accuracy parameters for the contrastenhanced MRI we obtained in this review are similar to those reported by Roberts et al (2018) for the same technique and better than those for contrast-enhanced CT scans in that same review. ${ }^{27}$ Another review assessing diffusion weighted MRI also showed accuracy parameters similar to ours. ${ }^{28} \mathrm{DWI}$ sensitivity was $81 \%$ (95\% CI: $67 \%$ $90 \%$ We also found that non-contrast MRI acts as a better surveillance tool than being a diagnostic tool for HCC. We also tried to assess the impact of chronic liver conditions, and use of DWI on the accuracy of the non-contrast MRI. We found that there was no change in the specificity and mild reduction in the sensitivity in case the patients present with cirrhosis/chronic hepatitis/ any chronic liver conditions. Similar finding was observed for the use of DWI in the imaging system. Further updated reviews should compare the performance of non-contrast MRI with other similar imaging techniques. ${ }^{29}$

However, our results need to be interpreted and inferred with caution, considering the quality and difference in methods among the included studies. For example, we found significance between-study variability. This heterogeneity can be attributed to the varying ethnicity of the study participants and to the differing risk factors and severity amongst the patients in the studies included. Deek's test 
results and the funnel plot pointed to the absence of publication bias. In addition, studies like Chung et al. 2011 21 included only hypervascular lesions and Hans et al $2018^{25}$ including only the initial HCC diagnosed patients leading to marked inflation in the pretest probability of HCCs in this cohort compared to general pool of at-risk patients. However, sensitivity analysis performed by excluding these studies also revealed sensitivity $(83 \%)$ and specificity (95\%) to be high.

Our review is the first meta-analysis assessing the accuracy of non-contrast MRI for the detection of HCC among high-risk patients, and it involved a large number of studies with high sample sizes. Most included studies showed high QUADAS-2 tool quality, and we found no significant publication bias adding to credibility of our metaanalysis.

Limitations of the study: First, we found a significance between-study variability in our analysis that limits our ability to infer or interpret the pooled findings. Second, the accuracy of the non-contrast MRI depends on multiple factors including some which we could not assess like the ethnicity, timing of the non-contrast MRI assessment, and severity and risk factors of the patients.

\section{CONCLUSION}

Our findings suggest that non-contrast MRI can be used for the detection of HCC. The use of non-contrast MRI in these patients can help in reducing the time spent with diagnostic procedures and also the healthcare costs. Largescale setting-specific longitudinal studies are required to establish non-contrast MRI as the standard assessment tool for all the high-risk patients.

Competing interests: None.

Funding: None

\section{REFERENCES}

1. Tejeda-Maldonado J, Garcia-Juarez I, Aguirre-Valadez J, González-Aguirre A, Vilatobá-Chapa M, ArmengolAlonso A, et al. Diagnosis and treatment of hepatocellular carcinoma: An update. World J Hepatol. 2015;7(3):362-376. doi: 10.4254 / wjh.v7.i3.362

2. Tzartzeva K, Obi J, Rich NE, Parikh ND, Marrero JA, Yopp A, et al. Surveillance Imaging and Alpha Fetoprotein for Early Detection of Hepatocellular Carcinoma in Patients with Cirrhosis: A Meta-analysis. Gastroenterology. 2018;154(6):1706-1718.e1. doi: $10.1053 /$ j.gastro.2018.01.064
3. Meissner HI, Smith RA, Rimer BK, Wilson KM, Rakowski W, Vernon SW, et al. Promoting cancer screening: Learning from experience. Cancer. 2004;101(5 Suppl):1107-1117. doi: 10.1002/cncr.20507

4. TanCH,LowS-CA,ThngCH.APASLandAASLDConsensus Guidelines on Imaging Diagnosis of Hepatocellular Carcinoma: A Review. Int J Hepatol. 2011;2011:519783. doi: 10.4061/2011/519783

5. Bruix J, Sherman M, American Association for the Study of Liver Diseases. Management of hepatocellular carcinoma: an update. Hepatology. 2011;53(3):1020-1022. doi: 10.1002/ hep.24199

6. Omata M, Lesmana LA, Tateishi R, Chen PJ, Lin SM, Yoshida $\mathrm{H}$, et al. Asian Pacific Association for the Study of the Liver consensus recommendations on hepatocellular carcinoma. Hepatol Int. 2010;4(2):439-474. doi: 10.1007/ s12072-010-9165-7

7. European Association For The Study Of The Liver, European Organisation For Research And Treatment Of Cancer. EASL-EORTC clinical practice guidelines: management of hepatocellular carcinoma. J Hepatol. 2012;56(4):908-943. doi: 10.1016/j.jhep.2011.12.001

8. Singal A, Volk ML, Waljee A, Salgia R, Higgins P, Rogers MAM, et al. Meta-analysis: surveillance with ultrasound for early-stage hepatocellular carcinoma in patients with cirrhosis. Aliment Pharmacol Ther. 2009;30(1):37-47. doi: 10.1111/j.1365-2036.2009.04014.x

9. Yoon JH, Park J-W, Lee JM. Noninvasive Diagnosis of Hepatocellular Carcinoma: Elaboration on Korean Liver Cancer Study Group-National Cancer Center Korea Practice Guidelines Compared with Other Guidelines and Remaining Issues. Korean J Radiol. 2016;17(1):7-24. doi: 10.3348/kjr.2016.17.1.7

10. Korean Society of Abdominal Radiology. Diagnosis of Hepatocellular Carcinoma with Gadoxetic Acid-Enhanced MRI: 2016 Consensus Recommendations of the Korean Society of Abdominal Radiology. Korean J Radiol. 2017;18(3):427-443. doi: 10.3348/kjr.2017.18.3.427

11. Whiting PF, Rutjes AWS, Westwood ME, Mallett S, Deeks JJ, Reitsma JB, et al. QUADAS-2: a revised tool for the quality assessment of diagnostic accuracy studies. Ann Intern Med. 2011;155(8):529-536. doi: 10.7326/0003-4819155-8-201110180-00009

12. Whang S, Choi MH, Choi J-I, Youn SY, Kim DH, Rha SE. Comparison of diagnostic performance of non-contrast MRI and abbreviated MRI using gadoxetic acid in initially diagnosed hepatocellular carcinoma patients: a simulation study of surveillance for hepatocellular carcinomas. Eur Radiol. 2020;30(8):4150-4163. doi: 10.1007/s00330-02006754-4

13. Jalli R, Jafari SH, Sefidbakht S, Kazemi K. Comparison of the Accuracy of DWI and Ultrasonography in Screening Hepatocellular Carcinoma in Patients with Chronic Liver Disease. Iran J Radiol. 2015;12(1):e12708. doi: 10.5812/ iranjradiol.12708

14. Min JH, Kim YK, Choi S-Y, Kang TW, Jeong WK, Kim $\mathrm{K}$, et al. Detection of recurrent hepatocellular carcinoma after surgical resection: Non-contrast liver MR imaging with diffusion-weighted imaging versus gadoxetic acidenhanced MR imaging. Br J Radiol. 2018;91(1090):20180177. doi: 10.1259/bjr.20180177

15. Hardie AD, Kizziah MK, Boulter DJ. Diagnostic accuracy of diffusion-weighted MRI for identifying hepatocellular carcinoma with liver explant correlation. J Med Imaging Radiat Oncol. 2011;55(4):362-367. doi: 10.1111/j.17549485.2011.02286.x 
16. Kim JS, Lee JK, Baek SY, Yun HI. Diagnostic performance of a minimized protocol of non-contrast MRI for hepatocellular carcinoma surveillance. Abdom Radiol (NY). 2020;45(1):211-219. doi: 10.1007/s00261-019-02277-9

17. Sutherland T, Watts J, Ryan M, Galvin A, Temple F, Vuong J, et al. Diffusion-weighted MRI for hepatocellular carcinoma screening in chronic liver disease: Direct comparison with ultrasound screening. J Med Imaging Radiat Oncol. 2017;61(1):34-39. doi: 10.1111/1754-9485.12513

18. Vietti Violi N, Lewis S, Liao J, Hulkower M, HernandezMeza G, Smith K, et al. Gadoxetate-enhanced abbreviated MRI is highly accurate for hepatocellular carcinoma screening. Eur Radiol. 2020;30(11):6003-6013. doi:10.1007/ s00330-020-07014-1

19. Chan MV, McDonald SJ, Ong Y-Y, Mastrocostas K, Ho E, Huo YR, et al. HCC screening: assessment of an abbreviated non-contrast MRI protocol. Eur Radiol Exp. 2019;3(1):49. doi: 10.1186/s41747-019-0126-1

20. Park MS, Kim S, Patel J, Hajdu CH, Do RKG, Mannelli $\mathrm{L}$, et al. Hepatocellular carcinoma: detection with diffusion-weighted versus contrast-enhanced magnetic resonance imaging in pretransplant patients. Hepatology. 2012;56(1):140-148. doi:10.1002/hep.25681

21. Chung J, Yu JS, Kim DJ, Chung J-J, Kim JH, Kim KW. Hypervascular hepatocellular carcinoma in the cirrhotic liver: diffusion-weighted imaging versus superparamagnetic iron oxide-enhanced MRI. Magn Reson Imaging. 2011;29(9):1235-1243. doi: 10.1016/j. mri.2011.07.025

22. Kim YK, Kim YK, Park HJ, Park MJ, Lee WJ, Choi D. Noncontrast MRI with diffusion-weighted imaging as the sole imaging modality for detecting liver malignancy in patients with high risk for hepatocellular carcinoma. Magn Reson Imaging. 2014;32(6):610-618. doi: 10.1016/j.mri.2013.12.021
23. Park HJ, Jang HY, Kim SY, Lee SJ, Won HJ, Byun JH, et al. Non-enhanced magnetic resonance imaging as a surveillance tool for hepatocellular carcinoma: Comparison with ultrasound. J Hepatol. 2020;72(4):718724. doi: 10.1016/j.jhep.2019.12.001

24. Shankar S, Kalra N, Bhatia A, Srinivasan R, Singh P, Dhiman RK, et al. Role of Diffusion Weighted Imaging (DWI) for Hepatocellular Carcinoma (HCC) Detection and its Grading on 3T MRI: A prospective study. J Clin Exp Hepatol. 2016;6(4):303-310. doi: 10.1016/j.jceh.2016.08.012

25. Han S, Choi JI, Park MY, Choi MH, Rha SE, Lee YJ. The Diagnostic Performance of Liver MRI without Intravenous Contrast for Detecting Hepatocellular Carcinoma: A Case-Controlled Feasibility Study. Korean J Radiol. 2018;19(4):568-577. doi: 10.3348/kjr.2018.19.4.568

26. Xu PJ, Yan FH, Wang JH, Shan Y, Ji Y, Chen C-Z. Contribution of diffusion-weighted magnetic resonance imaging in the characterization of hepatocellular carcinomas and dysplastic nodules in cirrhotic liver. J Comput Assist Tomogr. 2010;34(4):506-512. doi: 10.1097/RCT.0b013e3181da3671

27. Roberts LR, Sirlin CB, Zaiem F, Almasri J, Prokop LJ, Heimback JK, et al. Imaging for the diagnosis of hepatocellular carcinoma: A systematic review and metaanalysis. Hepatology. 2018;67(1):401-421. doi: 10.1002/ hep. 29487

28. Wu LM, Xu JR, Lu Q, Hua J, Chen J, Hu J. A pooled analysis of diffusion-weighted imaging in the diagnosis of hepatocellular carcinoma in chronic liver diseases. J Gastroenterol Hepatol. 2013;28(2):227-234. doi: 10.1111/ jgh.12054

29. Hafeez M, Nadeem M, Ahmed M, Rehman F. Hepatocellular Carcinoma (HCC), Where do we stand? Current situation. Pak J Med Sci. 2020; 36(3) doi: 10.12669/ pjms.36.3.1594 